\title{
Safety and Health Promotion Program Implementation of PT Varley Indonesia
}

\author{
Rizqi Suryaramadhanty, Siti Rahmah Hidayatullah Lubis \\ Public Health Study Program, Faculty of Medicine and Health Sciences \\ Syarif Hidayatullah State Islamic University Jakarta, Indonesia \\ ramadhanty23@gmail.com
}

\begin{abstract}
Every work place has its specific risk of accident which can be the main problem for some companies. One of the solution to minimize those outcome is by implementing the safety and health promotion program. These program can control the unsafe act of the worker and the unsafe condition of the work place as a basic cause for accident or health disorder. The aim of this study was to describe how safety and health promotion program is implemented in PT Varley Indonesia. This study aims to describe the implementation of safety and health promotion program in PT Varley Indonesia. Observation, in-depth interview with the workers, literature study, and document research had been done to complete the result of this study. The results of this study were PT Varley Indonesia has the health bulletin, banner, poster, training program, toolbox meeting, fruit's day, the gymnastic's Friday, HSE meeting, and reward and punishment program. The objective of those programs are to improve the accident and health disorder prevention program and to increase knowledge and awareness of worker in occupational safety and health. The result is showing that the implementation of safety and health promotion program has been suitably done as it is in HSE Policy and OHSAS 18001 procedure refer to PT Varley Indonesia, but reward and punishment program still in improvement phase. It is suggested for PT Varley Indonesia to improve each program of safety and health promotion program.
\end{abstract}

Keywords-Safety and Health Promotion Program, PT Varley Indonesia

\section{INTRODUCTION}

In this industrial era, the development of technology and industrial activity are increase significantly. One of those are oil and gas industry and also power plant industry. Oil consumption all over the world still increase by the time, $3.100-3.600 \mathrm{Mt}$ each year from 2000 to 2015. Specifically, in Asia the need of oil also increases, $800-1.200 \mathrm{Mt}$. It also happened in Indonesia, from 2013 to 2015, started from $71 \mathrm{Mt}$ to $73 \mathrm{Mt}$ [1]. Not only oil and gas, the needs of electrical energy is also increase. Electrical consumption goes high from 2000 to 2015 from 13.500 TWh to 20.000 TWh. In Asia, 3.500 TWh in 2000 to 8.000 TWh in 2015. And in Indonesia for the last 5 years, from $160 \mathrm{TWh}$ in 2011 to $204 \mathrm{TWh}$ in 2015 [2]. Based on the data, to fulfill the demand of the needs, maintenance of the process industry should be taken continually. Maintenance is extremely needed to make sure all of the process industry is going well [3].

Operated since 2004, PT Varley Indonesia is a corporation which provides maintenance and repairing service. Main client of this company are oil and gas industry and power plant industry. In general, there are eleven steps of job activity in PT Varley Indonesia, incoming, dismantling, cleaning, welding, machining, repairing, assembling, testing, painting, packaging, and outgoing. The demand of maintenance and repairing service are rising recently so it can be said that the risk of safety and health hazard are increasing as well. To control that kind of hazard in each process of job activity, such as welding, cleaning, sandblasting, etc, safety and health promotion program should be taken.

The compliance of safety and health promotion program in PT Varley Indonesia refers to its legal aspect. Law Regulation No. 11970 about safety work mention that every company has a duty to prevent the accident by doing a coaching program about controlling safety and health hazard [4]. Then Law Regulation No. 132003 about employment, every company has a duty to protect the worker for their safety to create the optimum productivity [5]. Refer to both law regulations, to implement the accident prevention and to increase the productivity, safety and health promotion program is an obligatory to every company.

\section{METHODS}

This research was conducted on February 2017 in Safety and Health Environment Division of PT Varley Indonesia, especially in safety and health promotion program. The aim of this research was to describe how safety and health promotion program was run in order to comply the regulation, Law Regulation in Indonesia about employment and its aspect about safety and health. This research was done by in-depth interview with some responsible workers, observation, and document research. 


\section{RESULT}

PT Varley Indonesia had several safety and health promotion program. All of them were comply to the law regulation. There were two categories of safety and health promotion program, the main program and additional program. The main program were HSE Bulletin, HSE Banner, HSE Meeting, toolbox meeting, and HSE training, while the additional program were MOSHE (Motivation Of Safety and Health Environment), Fruit day, gymnastics day, and reward and punishment program.

TABLE I. DESCRIPTIVE RESULT

\begin{tabular}{|c|c|c|}
\hline Program & Standard & Compliance \\
\hline HSE Bulletin & $\begin{array}{l}\text { published once in a month refers to } \\
\text { Law Regulation of Indonesia no. } 13 \\
2003 \text { and OHSAS } 18001: 2007\end{array}$ & Complied \\
\hline HSE Banner & $\begin{array}{l}\text { published once in a year refers to } \\
\text { Law Regulation of Indonesia no. } 13 \\
2003 \text { and OHSAS } 18001: 2007\end{array}$ & Complied \\
\hline HSE meeting & $\begin{array}{l}\text { conducted in every end of the month } \\
\text { refers to Law Regulation of } \\
\text { Indonesia no. } 132003 \text { and OHSAS } \\
18001: 2007\end{array}$ & Complied \\
\hline $\begin{array}{l}\text { Toolbox } \\
\text { meeting }\end{array}$ & $\begin{array}{l}\text { conducted in everyday refers to Law } \\
\text { Regulation of Indonesia no. } 132003 \\
\text { and OHSAS } 18001: 2007\end{array}$ & Complied \\
\hline Training & $\begin{array}{l}\text { conducted in every month refers to } \\
\text { Law Regulation of Indonesia no. } 1 \\
\text { 1970, Law Regulation of Indonesia } \\
\text { no. } 132003 \text {, and OHSAS } 18001 \text { : } \\
2007\end{array}$ & Complied \\
\hline MOSHE & $\begin{array}{l}\text { published once in a week refers to } \\
\text { Law Regulation of Indonesia no. } 13 \\
2003 \text { and OHSAS } 18001: 2007\end{array}$ & Complied \\
\hline Fruitday & $\begin{array}{l}\text { shared on fruit day every } \\
\text { Wednesday refers to Minister } \\
\text { Regulation of Employment No. } 10 \\
2016\end{array}$ & Complied \\
\hline Gymnastic day & $\begin{array}{l}\text { held on Friday morning refers to } \\
\text { Minister Regulation of } \\
\text { Employment No. } 31982\end{array}$ & Complied \\
\hline $\begin{array}{l}\text { Reward and } \\
\text { punishment }\end{array}$ & $\begin{array}{l}\text { announced every month and every } \\
\text { year refers to Minister Regulation of } \\
\text { Employment No. } 102016\end{array}$ & $\begin{array}{c}\text { Not } \\
\text { complied }\end{array}$ \\
\hline
\end{tabular}

Table I. shows descriptive analysis result in this research. It is known that all the program had its regulation and standard but not all of them were complied to it.

\section{DISCUSSION}

\section{A. Safety Culture in PT Varley Indonesia}

The objective of safety and health promotion program was to implement safety and health culture in a workplace. For its achievement safety culture in a workplace can be divided into five categories (pathological, reactive, calculative, proactive, and generative) [6]. Refer to the result of this research, PT Varley Indonesia comply to calculative category which is mean that the implementation of safety and health in a workplace had been done well to control all of the hazard but the awareness of the worker to participate preventing/controlling the hazard still in improvement phase, they're still need some warning to do so.

Beside the compliance to the law regulation, PT Varley Indonesia had its standard for some programs. Its standard called safety policy and standard operational procedure (SOP). Safety and health promotion program included in safety policy PT Varley Indonesia point 4 "PT Varley Indonesia will always try to give training and education to all workers about safety and health in the workplace". Other than that, standard operational procedure for safety and health promotion program refers to OHSAS 18001: 2007 point 4.4.3 about HSE communication (consultation and participation). Standard operational procedure (SOP) is a guide that contain some directions for what the company should done to achieve the objective programs. Standard operational procedure is needed for the management to take a decision in everything that related to the job activity [7].

\section{B. Safety Promotion in PT Varley Indonesia}

There are some steps for safety promotion in a workplace [8]. The seven steps are as follows:

1. Getting management support

2. Creating group coordination.

3. Getting done the need analysis and analyzing issues that related to occupational health.

4. Identifying priority issue and finding the intervention's objection.

5. Designing the intervention and activity plan.

6. Implementing the intervention.

7. Evaluating the intervention implementation process and its effectiveness.

Based on the research's result, PT Varley Indonesia suitable to the five steps except for point two and seven. It's quiet hard to create a group coordination because not all of the workers had the same perspective about the important of safety and health in a workplace. Most of them still had "safety and health in the workplace is the HSE division's responsibility" mindset. In the other hand, it's quiet hard too to measure the effectiveness of the implementation of safety and health promotion program because most of the program that required 
the awareness of the workers like, HSE bulletin, HSE Banner, and other media need a long time to see the difference of their behavior in safety and health in a workplace. The indicator to evaluate the evaluation the program is just by making sure that the program is done completely to the standard operational procedure OHSAS 18001:2007.

\section{Approachment and Compliance of Safety and Health Promotion Program In PT Varley Indonesia}

In implementing safety and health promotion program, PT Varley Indonesia used the educational approach that focused on increasing the role of education to develop the knowledge of the workers so that their behavior could change in a positive way. The benefit of using this approach is that it is possible for some workers to develop their knowledge and change their behavior by themselves but the weakness is taking too much time to see the outcome if there is no will that come through the workers themselves to change their behavior [9].

Based on the research result, all of the implementation of safety and health promotion program were complied to the procedure and the procedure will be updated adjusting to the implementation of the program by the time. All of safety and health promotion program were complied to the regulation or standard except for reward and punishment program that still in improvement phase.

\section{REFERENCES}

[1] Enerdata, Global Energy Statistical Yearbook 2016 - Oil products domestic consumption, 2016.

[2] Enerdata, Global Enerdy Statistical Yearbook 2016 Electricity domestic consumption, 2016

[3] I. Apri Heri. "Maintenance Production Machines Management (Manajemen Pemeliharaan Mesin-Mesin Produksi)", Agricultre Research, in press.

[4] Law regulationof Indonesia No. 1 1970, "Safety in a workplace", 1970

[5] Law regulation of Indonesia No. 13 2003. "Employment", 2003

[6] P. Kim Y. P. Park J, "Creating a Culture of Prevention in Occupational Safety and Health Practice", International Journal of Safety, in press.

[7] K. Alfiani Patrik, "Implementation of standard operational procedure in government duty of Malayang, Manado. (Penerapan Standar Operasional Prosedur Dalam Pelaksanaan Tugas Pemerintah Kecamatan Malalayang Kota Manado)", E-journal Sam Ratulangi University, in press.

[8] F. Carl I. A. Diane D. A. M. Elaine, "Health Promotion Programs from Theory to Practice", International Journal of Health, in press.

[9] G. Mary. B. Jane Goodman, "A Guide to Practical Health Promotion. International Journal of Health", in press. 